\title{
Charcoal production through selective logging leads to degradation of dry woodlands: a case study from Mutomo District, Kenya
}

\author{
Geoffrey M NDEGWA ${ }^{1,2,3^{*}}$, Udo NEHREN ${ }^{2}$, Friederike GRüNINGER ${ }^{1}$, Miyuki IIYAMA ${ }^{3,4}$, \\ Dieter ANHUF ${ }^{1}$ \\ ${ }^{1}$ Department of Physical Geography, University of Passau, Passau 40, 94036, Germany; \\ ${ }^{2}$ Institute for Technology and Resources Management in the Tropics and Subtropics, TH Köln University of Applied Sciences, \\ Cologne 2, 50679, Germany; \\ ${ }^{3}$ The World Agroforestry Centre, Nairobi 30677-00100, Kenya; \\ ${ }^{4}$ The Japan International Research Center for Agricultural Sciences (JIRCAS) 1-1 Owashi, Tsukuba, Ibaraki Prefecture \\ 305-0851, Japan
}

Abstract: Provision of woodfuel is an important ecosystem service of dry forests and woodlands. However, charcoal production through selective logging of preferred hardwood species has the potential to alter the physiognomic composition of the residual or re-growth woodlands and may lead to their deterioration and degradation. This study, conducted through forest inventory in Mutomo District in Kenya, assessed the impact of charcoal production on unprotected dry woodlands in terms of tree density, targeted species basal area, species richness, evenness and Shannon diversity. The parameters of the disturbed woodlands were evaluated for significant differences with those of the neighbouring protected Tsavo East National Park, which served as a reference for an ecologically undisturbed ecosystem. By evaluating a consequence of tree harvesting for charcoal production, this study confirmed the overall significant differences between the protected and unprotected woodlands in all the tested parameters. To confirm if the differences in the land-covers of the woodlands had any influence on their degradation, all mentioned parameters were compared between the four differentiated classes and their respective control plots in the protected areas. At the "land-cover level", the statistically significant difference in the basal area of tree species preferred for charcoal production between the protected and unprotected open trees confirms that the class with a high density of large mature trees is the prime target of charcoal producers. In addition, there seems to be a general trend of lower values of tree species richness, evenness and Shannon diversity for the unprotected woodlands subjected to charcoal production. On the other hand, the disturbed woodlands display the potential to recover through their comparably high saplings density. The findings make an important contribution to the discourse on the impact of charcoal production in dry woodlands, a topic that is highly controversial among researchers.

Keywords: charcoal burning; forest degradation; selective harvesting; Acacia-Commiphora bushland; coppicing

Citation: Geoffrey M NDEGWA, Udo NEHREN, Friederike GRüNINGER, Miyuki IIYAMA, Dieter ANHUF. 2016. Charcoal production through selective logging leads to degradation of dry woodlands: a case study from Mutomo District, Kenya. Journal of Arid Land, 8(4): 618-631. doi: 10.1007/s40333-016-0124-6

Dry woodlands are vegetation formations which comprise of scrubs, bushlands, thickets, wooded grasslands and dense woodlands (Chidumayo and Gumbo, 2010). They occur in climates with

*Corresponding author: Geoffrey M NDEGWA (E-mail: gefmaina@yahoo.com)
Received 2015-07-23; revised 2015-11-12; accepted 2016-03-09
C Xinjiang Institute of Ecology and Geography, Chinese Academy of Sciences, Science Press and Springer-Verlag Berlin Heidelberg 2016 
annual rainfall of 300 to $1,200 \mathrm{~mm}$ and a dry period of five to ten months (FAO, 2000). These woodlands are an important source of ecosystem services to the agro-pastoral and pastoral communities living within and around them (Maass et al., 2005). They provide woodfuel, timber and non-timber products and also play an important role in climate regulation, soil fertility maintenance, flood control, carbon sequestration and storage among others (Maass et al., 2005; Grace et al., 2006; Becknell et al., 2012).

In many Sub-Saharan African countries, dry woodlands have been exploited for charcoal production (Arnold et al., 2006; Ahrends et al., 2010; Chidumayo and Gumbo, 2010, 2013) mostly through selective logging of hardwood species which are preferred for their dense charcoal and high caloric value (Butz, 2013). Well-planned selective logging, especially of large canopy trees, improves light penetration to the understory vegetation, thus stimulating natural regeneration processes (Zida et al., 2007). However, selective logging targeting specific species has the potential to materially alter the composition and physiognomy of the woodlands and may lead to undesirable ecological consequences (Ahrends et al., 2010).

The debate on the impact of woodfuel extraction (firewood and charcoal) has never been conclusive (Butz, 2013; Chidumayo and Gumbo, 2013). Some authors argue that charcoal production leads to degradation of woodlands, thus negatively impacting on their capacity to provide ecosystem services to sustain livelihoods (Ahrends et al., 2010; Iiyama et al., 2014). Others however dispute this assertion by stating that unless the land is put under cultivation, the woodlands have the capacity to regenerate to their near original state (Arnold et al., 2006).

There is a large body of empirical and theoretical literature on the importance of charcoal as an energy source and its economic importance at the micro and macro levels in Sub-Saharan African countries (Arnold et al., 2006; Chidumayo and Gumbo, 2013; Iiyama et al., 2014). However, the effect of charcoal production on the woodland structure, diversity and dynamics has received little attention (FAO, 2000; Ahrends et al., 2010) mostly due to methodological and data constraints (Archibald and Scholes, 2007; Chidumayo and Gumbo, 2010; De la Barreda-Bautista et al., 2011). The use of national forest inventories to monitor the dry woodlands in Sub-Saharan Africa is constrained by lack of data in most of the countries (Chidumayo and Gumbo, 2010). Furthermore, annual changes in leaf display and the presence of a substantial grass layer make the use of remote sensing techniques for change detection and mapping highly susceptible to errors (Archibald and Scholes, 2007; De la Barreda-Bautista et al., 2011). Vegetation trend analysis could be used for monitoring, but high costs and the large temporal and spatial scales required to give good empirical results limit their adoption (Grainger, 1999; le Polain de Waroux and Lambin, 2012).

Faced with these challenges, this study assessed the ecological impact of charcoal production on the unprotected dry woodlands in Mutomo District in Kenya by comparing their current status with those in the neighbouring protected Tsavo East National Park. Both woodlands fall in the same agro-ecological zone. The unprotected woodlands have been subjected to selective logging of hardwood tree species for charcoal production especially over the last decade, with most of the charcoal destined for the capital city of Nairobi (GOK, 2013). In contrast, the woodlands in the national park, though with minor signs of perturbation from wild animals, are largely undisturbed and therefore serves as a reference for a near-natural ecosystem. The study area has four land-cover classes namely: open trees, thickets, shrubs, and herbaceous vegetation (FAO, 2002; Table 1), whose natural vegetation composition varies due to differences in environmental and biophysical conditions. The density and sizes of the trees are highest in the open trees land-cover class, which makes it the most suitable for charcoal production activities, while in contrast, the herbaceous vegetation class has the lowest tree density and sizes. Bearing in mind these and other differences between the land-cover classes, the study not only aimed to determine whether the intensity of exploitation (and consequent degradation) has an overall impact on the unprotected woodland, but also tried to explain if there exists significant differences between the land-cover classes. To this end, two research questions were addressed: (a) Are there significant differences in the overall degradation status between the plots in the protected national park woodlands and 
the unprotected woodland? (b) Does the different land use history and environmental parameters of the four different land-cover types affect their degradation status?

In answering these questions, the study provides the much-sought-after empirical evidence on the impact of charcoal production through selective logging on the dry woodlands, which will also help relevant authorities to give advice on suitable sustainable management practices.

\section{Materials and methods}

\subsection{Study area}

The study was conducted in the southern part of Mutomo District of Kitui county in the eastern province of Kenya. The district has a bi-modal rainfall pattern that ranges between $500-1,050$ $\mathrm{mm} / \mathrm{a}$ with $30 \%$ reliability (GOK, 2009). It has an area of $20,402 \mathrm{~km}^{2}$, of which $6,290 \mathrm{~km}^{2}$ is located within Tsavo East National Park. The study sites cover an area of about $780 \mathrm{~km}^{2}$, and stretch $10 \mathrm{~km}$ on either side of the boundary of the Tsavo East National Park (Fig. 1).
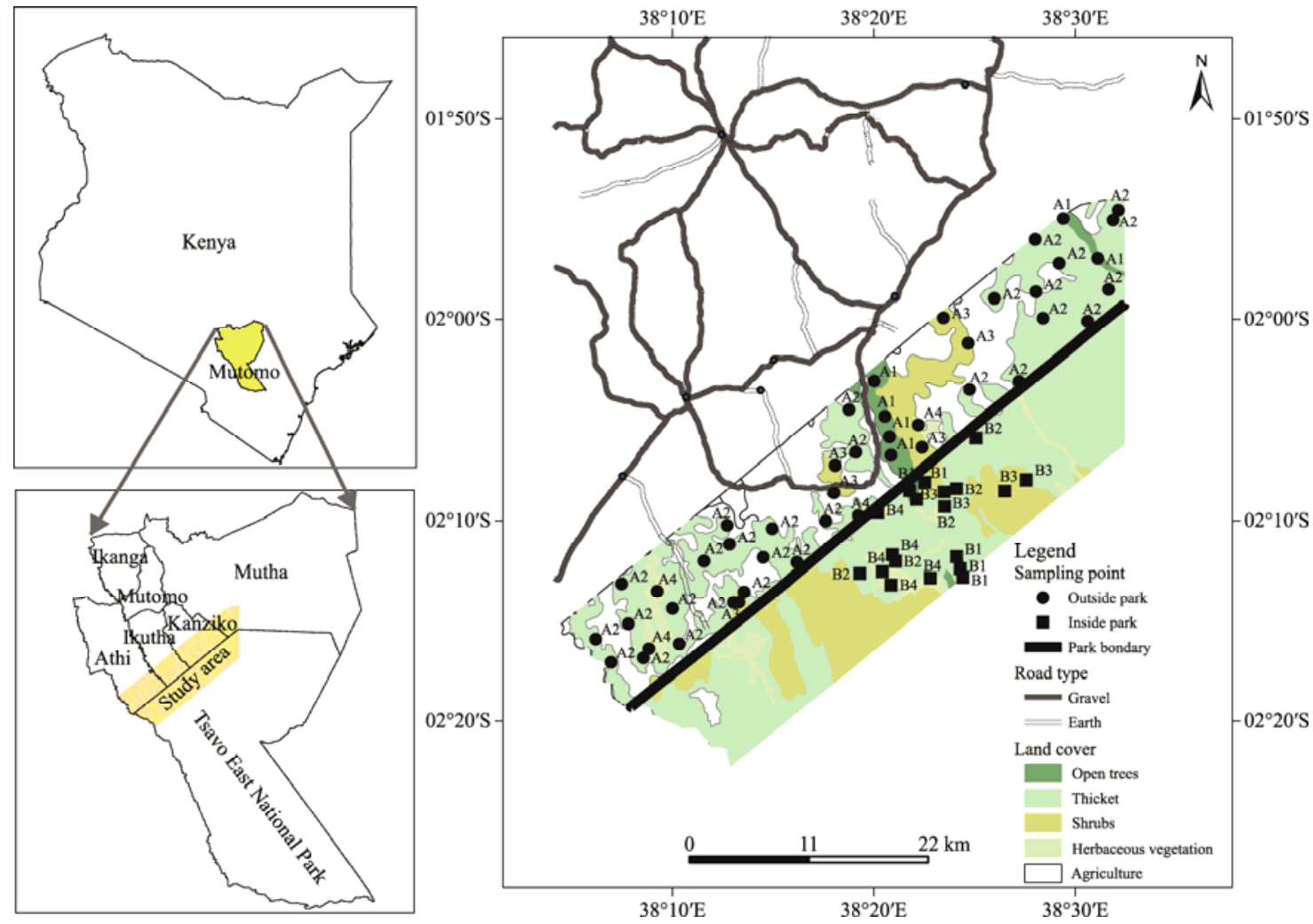

Fig. 1 Map of the study area

The national park was established in 1948 and has been protected with an electric fence since 2003 to reduce human-wildlife conflicts. Human encroachment into the woodlands was however low even before the fence was erected due to constant patrols by armed game rangers. Control plots in the national park were set up in the northern part, which has a low elephant population (considered the greatest agent of degradation in the Tsavo ecosystem) of between 0.06-0.24 elephants $/ \mathrm{km}^{2}$ (Ngene et al., 2013), hence minimal related degradation.

The vegetation of the study area belongs to the Southern Acacia-Commiphora Bushland and Thicket Ecoregion, which is part of the tropical and subtropical grasslands, savannas, and shrublands biome according to the World Wildlife Fund classification of terrestrial biomes and ecoregions (http://worldwildlife.org/biomes). The ecoregion covers about $36.4 \%$ of the country, mostly in the eastern side, and is characterized by dense bushlands of 3-5 $\mathrm{m}$ high with 
occasionally emergent trees of about $10 \mathrm{~m}$ in height. The dominant tree species are Acacia sp. and Commiphora sp. (Millington et al., 1994).

According to FAO (2002), the area is subdivided into seven land-cover classes, with the thickets land-cover class being most dominant (Table 1). The vegetation composition varies depending on topography, hydrological conditions, and soil properties. The open trees land-cover class is predominantly found on hills, most of which are considered important water catchment areas. As a result, the local authorities discourage establishment of human settlements but unauthorized exploitation for both timber and non-timber products still takes place (Eriksen et al., 2006). The shrubs and thickets land-cover classes are mostly found in flat plains with reddish and sandy soils. The herbaceous vegetation land-cover class is mostly confined to floodplains with poor clayey soils making them less suitable for habitation (GOK, 2009).

Table 1 Land-cover classes in the study area reclassified according to FAO (2002)

\begin{tabular}{|c|c|c|c|c|c|c|}
\hline \multirow{2}{*}{ FAO ID } & \multirow{2}{*}{ FAO name } & \multirow{2}{*}{ New name } & \multirow{2}{*}{ Description } & \multirow{2}{*}{$\begin{array}{c}\text { Area } \\
\left(\mathrm{km}^{2}\right)\end{array}$} & \multicolumn{2}{|c|}{ Number of plots } \\
\hline & & & & & Unprotected & Protected \\
\hline FR-3 & $\begin{array}{l}\text { Open trees }(65 \%-40 \% \\
\text { crown cover) }\end{array}$ & Open trees & $\begin{array}{l}\text { Comprised of trees ranging } \\
\text { from } 2-7 \mathrm{~m} \text { tall at a density } \\
\text { between } 15 \%-65 \%\end{array}$ & 32.45 & 6 & 5 \\
\hline FR-5 & $\begin{array}{l}\text { Closed to open woody } \\
\text { vegetation }\end{array}$ & Thickets & $\begin{array}{l}\text { Comprised of a continuous } \\
\text { shrubs layer } 0.5-5 \mathrm{~m} \text { tall at } \\
15 \%-65 \% \text { density with } \\
\text { emergent trees }\end{array}$ & 606.05 & 29 & 5 \\
\hline FR-6 & Closed shrubs & Shrubs & Dominated by shrubs $0.5-5$ & & & \\
\hline FR-7 & Open (general) shrubs & & $\begin{array}{l}\mathrm{m} \text { tall at } 15 \%-40 \% \text { density; } \\
\text { a herbaceous layer and }\end{array}$ & 194.17 & 6 & 4 \\
\hline RL-2 & $\begin{array}{l}\text { Shrub savannah or tree } \\
\text { and shrub savannah }\end{array}$ & & sparse trees & & & \\
\hline RL-4 & $\begin{array}{l}\text { Open to closed } \\
\text { herbaceous vegetation }\end{array}$ & $\begin{array}{l}\text { Herbaceous } \\
\text { vegetation }\end{array}$ & $\begin{array}{l}\text { Dominated of a herbaceous } \\
\text { layer } 0.03-3 \mathrm{~m} \text { tall at } 15 \%\end{array}$ & & & \\
\hline RL-1 & $\begin{array}{l}\text { temporarily flooded } \\
\text { Open to closed } \\
\text { herbaceous vegetation }\end{array}$ & & $\begin{array}{l}\text { to more than } 65 \% \text { density } \\
\text { plus some sparse trees } \\
\text { and/or shrubs }\end{array}$ & 48.08 & 4 & 5 \\
\hline
\end{tabular}

Almost all the residents of Mutomo District are subsistence farmers practicing rain-fed agriculture of drought resistant crops like maize, millet, cowpeas, green grams and beans. However, charcoal production has become a full-time economic activity over the last decade (GOK, 2013) due to: (a) cyclic droughts and unpredictable weather conditions which hamper agricultural activities; (b) poverty; (c) lack of alternative sources of income; and (4) degraded soils hence low agricultural potential. As a consequence, charcoal production is reported to have increased by over two-fold from $4 \times 10^{5}$ bags, each weighing $35 \mathrm{~kg}$, in 2001 (Mugova, 2009) to over $1 \times 10^{6}$ bags in 2013 (GOK, 2013).

\subsection{Sampling and data collection}

The study was done by conducting a forest inventory of the woodlands in the southern part of Mutomo District and in the northern part of Tsavo East National Park between December 2012 and January 2013. This was after a short period of rainfall; therefore the vegetation was green making it easy to clearly identify the saplings by species.

The seven FAO land-cover classes present were reclassified based on their similarities into four to ease interpretation (Table 1). According to FAO (2002), the protection status does not alter the biophysical conditions of the land-cover types.

A total of 64 random points were generated using Arc GIS software version 10.1 and their coordinates were recorded. Sampling plots falling in areas converted to agricultural land since FAO-classification in 2002 were excluded from the study. The coordinates were located using a GPS and square sampling plots measuring $20 \mathrm{~m} \times 20 \mathrm{~m}$ were established with the coordinates as the centres of the plots. A total of 45 plots were set up in the unprotected woodlands while 19 control plots were established inside the national park. The majority of the plots (29) were located in the thickets land-cover class which accounts for about $68 \%$ of the natural vegetation in the 
study area. One plot in the thickets land-cover class of unprotected woodlands did not have any mature trees and was omitted from the analysis.

All the trees were identified on species level with the help of the local forest officers according to the APG (Angiosperm Phylogeny Group) taxonomic system (The Angiosperm Phylogeny Group, 2009). Trees with a diameter at breast height $(\mathrm{DBH})$ of $\geq 5 \mathrm{~cm}$ were measured and recorded as mature trees usable for charcoal production. Trees below 5-cm DBH were recorded as saplings. Tree stumps were identified from their bark properties and their root collar diameters recorded. Leaves and bark of any individual tree or stump difficult to identify were collected and forwarded to the University of Nairobi Herbarium for identification. Finally, the number of charcoal kilns within a radius of $50 \mathrm{~m}$ from the centre of each plot within the unprotected woodlands was recorded.

\subsection{Data analysis}

The raw data were entered and analyzed using the IBM SPSS Statistics for Windows version 17.0 and Canoco for Windows version 4.5. Tree species data were generated by the mean DBH of the respective species, and categorized as hard (i.e. those preferred for charcoal production as they produce dense charcoal; this categorization is based on the local people interpretation according to the density of charcoal produced and not on the scientific classification of angiosperms (hardwoods) and gymnosperms (softwoods)) or soft (i.e. not preferred for charcoal production) using information collected from the District Forest Officer and local residents.

Calculation of tree and saplings density and regression analysis of tree stumps with charcoal kilns were done using IBM SPSS Statistics. SPSS was also used to test for significant differences between the protected and unprotected woodlands as well as between the four land-cover classes with respect to tree density, basal area, species richness, Shannon diversity, and evenness. As the data were not normally distributed, non-parametric pairwise Mann-Whitney U tests were conducted.

Using Canoco, a canonical correspondence analysis (CCA; Ter Braak and Šmilauer, 2002) was employed to visualize the pattern of community variation between the samples and to explain the differences in mature tree species composition by their differences in the environmental variables (Ter Braak, 1987), namely: (a) land cover; (b) protection status; (c) numbers of kilns; (d) numbers of tree stumps; and (e) number of saplings. The above-mentioned diversity and dominance measures (alpha-diversity, defined as tree species richness per sample plot; Whittaker, 1972), Shannon diversity, and evenness (Pielou, 1975) were extracted from the Canoco output statistics.

\section{Results}

\subsection{Tree composition}

A total of 44 tree species belonging to 18 families were identified in the study area. Amongst them, 22 were considered hardwoods and preferred for charcoal production while 22 were considered soft (Table 2). Of the 44 tree species identified, seven belong to the genus Acacia and five to that of Commiphora. This is in agreement with Millington et al. (1994) and Mutiti (2010) findings that Acacia sp. and Commiphora sp. are the most dominant trees in the Acacia-Commiphora bushlands.

A pairwise comparison was done between the protected and unprotected woodlands to test if there were any significant differences in terms of mature trees and saplings density, basal areas of both hardwoods preferred for charcoal production, basal area of softwoods, species richness, evenness and Shannon diversity (Table 3). The Mann-Whitney U tests showed there were significant differences between the protected and unprotected woodlands in terms of mature trees density $(\mathrm{U}=580.50, P=0.024)$, hardwoods basal area $(\mathrm{U}=596.00, P=0.013)$, species richness $(\mathrm{U}=623.00, P=0.012)$, evenness $(\mathrm{U}=623.00, P=0.002)$ and Shannon diversity $(\mathrm{U}=612.00$, $P=0.004)$. While during the field studies no signs of anthropogenic perturbation were detected in the protected woodlands, tree stumps and charcoal kilns were spotted in most of the unprotected woodlands. The latter are clear indicators for charcoal production. 
Table 2 List of species identified in the study area

\begin{tabular}{|c|c|c|c|}
\hline Botanical name & Family name & Local name & Hard/soft wood \\
\hline Acacia gerradii Benth. & Fabaceae & Musuisui & Hard \\
\hline Acacia mellifera (Vahl) Benth. & Fabaceae & Muthia & Hard \\
\hline Acacia nilotica (Benth) Brenan. & Fabaceae & Kisemei & Hard \\
\hline Acacia lahai Benth. & Fabaceae & Kikaiki & Hard \\
\hline Acacia senegal (L.) Willd. & Fabaceae & Kingolola & Hard \\
\hline Acacia seyal Del. & Fabaceae & Kinunga & Hard \\
\hline Acacia tortilis (Forssk.) Hayne. & Fabaceae & Muaa & Hard \\
\hline Albizia amara Boivin. & Fabaceae & Kiundua & Hard \\
\hline Albizia anthelmintica Brongn. & Fabaceae & Kуоа & Soft \\
\hline Berchemia discolor Hemsley. & Rhamnaceae & kisaaya & Hard \\
\hline Balanites aegyptica (L.) Del. & Zygophyllaceae & Kilule & Hard \\
\hline Boscia coriacea Pax. & Capparaceae & Isivu & Soft \\
\hline Cassia abbreviata Oliv. & Fabaceae & Kyarandathe & Hard \\
\hline Combretum collinum Fres. & Combretaceae & Itithi & Hard \\
\hline Combretum exalatum Engl. & Combretaceae & Iveti ya Ngumba & Soft \\
\hline Commiphora africana (A. Rich.) Engl. & Burseraceae & Ikuu & Soft \\
\hline Commiphora baluensis Engl. & Burseraceae & & \\
\hline Commiphora ellenbeckii Engl. & Burseraceae & Kakunga atemi & Soft \\
\hline Commiphora holtiziana Engl. & Burseraceae & Kang'uamazi & Soft \\
\hline Commiphora mildbraedii Engl. & Burseraceae & Yongwa & Soft \\
\hline Dalbergia melanoxylon Guill. et Perrott. & Fabaceae & Muvingo & Hard \\
\hline Delonix elata (L.) Gamble. & Fabaceae & Muange & Hard \\
\hline Dombeya rotundifolia Hochst. & Malvaceae & Muvau & Hard \\
\hline Erythrina abyssinica Lam. ex DC. & Fabaceae & Ilusi & Soft \\
\hline Ficus thonningii Blume. & Moraceae & Kiumo & Soft \\
\hline Gardenia volkensii K. Schum. & Rubiaceae & Mulungulu & Soft \\
\hline Grewia bicolor Juss. & Tiliaceae & Ilawa & Hard \\
\hline Hymenodictyon parvifolia Oliv. & Lauraceae & Mulinditi & Hard \\
\hline Lannea rivae (Chiov.) Sacleux. & Anacardiaceae & Kithalwa & Soft \\
\hline Lannea schweinfurthii (Engl.) Kokwaro. & Anacardiaceae & Kyuasi & Soft \\
\hline Maena crassifolia & Capparacea & Kyesense & Hard \\
\hline Maena krikrii & Capparacea & Mutungathi & Soft \\
\hline Saba comorensis (Boj.) Pichon. & Apocynaceae & Kyongoa & Soft \\
\hline Salvadora persica L. & Salvadoraceae & Mukayau & Soft \\
\hline Sterculia africana (K. Scum.) Fiori. & Malvaceae & Kyusya & Soft \\
\hline Strychnos decussata (Pappe) Gilg. & Loganiaceae & Kitolongue & Soft \\
\hline Strychnos spinosa Lam. & Loganiaceae & Kyae & Soft \\
\hline Synadenium glaucescens Pax. & Euphorbiaceae & Kyatha & Soft \\
\hline Teclea simplicifolia (Engl.) Verdoorn. & Rutaceae & Mutuiu & Hard \\
\hline Terminalia kilimandscharica Engl. & Combretaceae & Kiuuku & Hard \\
\hline Terminalia orbicularis Engl. \& Diels. & Combretaceae & Ikoo & Soft \\
\hline Terminalia prunioides Lawson. & Combretaceae & Mutoo & Hard \\
\hline Thylachium thomasii Gilg. & Capparaceae & Kitungu & Soft \\
\hline Tithonia diversifolia (Hemsley) A. Gray. & Asteraceae & Kilaa & Hard \\
\hline
\end{tabular}


Table 3 Pairwise comparisons of selected parameters between the protected and unprotected woodlands

\begin{tabular}{|c|c|c|c|c|}
\hline \multirow[b]{2}{*}{ Parameter } & \multicolumn{2}{|c|}{ Median } & \multirow[b]{2}{*}{ Mann-Whitney U } & \multirow[b]{2}{*}{ Two-tailed $P$} \\
\hline & $\begin{array}{c}\text { Protected } \\
\text { woodlands } \\
\end{array}$ & $\begin{array}{c}\text { Unprotected } \\
\text { woodlands }\end{array}$ & & \\
\hline Overall tree basal area $\left(\mathrm{hm}^{2}\right)$ & 4.45 & 5.09 & 366.00 & 0.366 \\
\hline Hardwoods basal area $\left(\mathrm{hm}^{2}\right)$ & 1.77 & 0.63 & 596.00 & $0.013^{*}$ \\
\hline Softwoods basal area $\left(\mathrm{hm}^{2}\right)$ & 2.01 & 4.22 & 304.50 & 0.071 \\
\hline Mature trees density (individuals $/ / \mathrm{hm}^{2}$ ) & 250 & 300 & 580.50 & $0.024^{*}$ \\
\hline Saplings density (individuals $/ \mathrm{hm}^{2}$ ) & 100 & 125 & 317.00 & 0.101 \\
\hline Species richness & 5.00 & 4.00 & 582.00 & $0.012^{*}$ \\
\hline Evenness & 0.98 & 0.96 & 623.00 & $0.002^{* *}$ \\
\hline Shannon diversity & 1.64 & 1.36 & 612.00 & $0.004^{* *}$ \\
\hline
\end{tabular}

Note: ${ }^{*}$ and ${ }^{* *}$ indicate significance at $P<0.05$ and $P<0.01$ levels.

A simple linear regression model (Fig. 2) showed that the number of tree stumps in the unprotected woodlands could be explained by the number of charcoal kilns $\left(R^{2}=0.73 ; P<0.0001\right)$, and that it increased with the increase in the number of kilns.

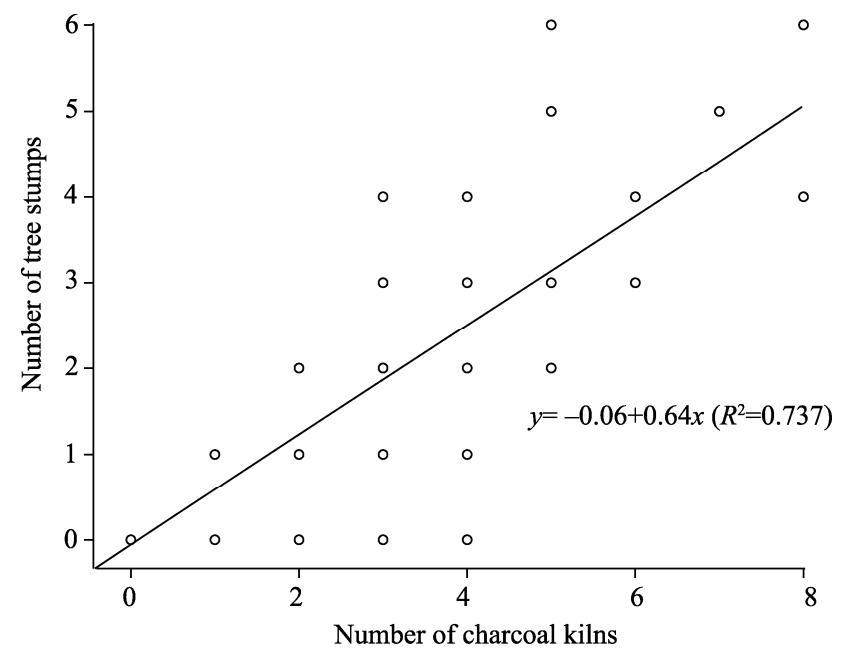

Fig. 2 Linear regression graph showing the relationship between the number of kilns and the number of tree stumps in dry woodlands: a case study from Mutomo District, Kenya

To test if the identified differences in tree composition between the protected and unprotected woodlands is also exhibited between similar land-cover classes, a pairwise comparison was done between corresponding classes. The Mann-Whitney $U$ test revealed a significant difference in basal area of hardwood trees preferred for charcoal production between the protected (median=1,743) and unprotected (median=261.6) open trees only $(\mathrm{U}=29.00, P=0.009)$. For the other land-cover classes there was no significant difference between the samples in unprotected woodlands and the respective control plots in the national park (thicket $U=110.50, P=0.063$; shrub $\mathrm{U}=16.00, P=0.470$; herbaceous vegetation $\mathrm{U}=10.00, P=1.000)$. Nevertheless, as Table 4 shows, the mean basal area of hardwood trees in the protected land-cover classes was generally higher than in the corresponding unprotected ones except in the herbaceous vegetation class.

The Mann-Whitney U test in Table 5 showed no significant difference in mature trees density between the protected and unprotected woodlands. When the same test was done for corresponding land-cover classes, there was also no significant difference as shown in Table 4. However, the median density of mature trees is generally higher in the protected woodland land-cover classes except in the open trees class. For saplings, the density was only significantly 
different between the protected and unprotected shrubs $(U=22.50, P=0.019)$. Nevertheless, the unprotected woodland had a higher sapling density except in the shrubs category.

The Mann-Whitney $U$ test between corresponding land-cover classes in the protected and unprotected woodlands showed that the Shannon diversity index was only significantly different between the thickets land-cover class $(\mathrm{U}=30.00, P=0.045)$. All the other parameters did not show a statistically significant difference (Table 6). Nevertheless, all the land-cover classes in protected woodlands showed higher medians in species richness, evenness and Shannon diversity values.

Table 6 also shows that the shrubs had more species than the other classes for both the protected (median=7.0) and unprotected (median=6.0) woodlands. On the other hand, the thickets and herbaceous vegetation in the unprotected woodlands had the lowest number of tree species per plot with a median of 4.0 and 3.5, respectively. The tree species evenness are generally high, indicating high equitability within protected as well as unprotected plots. Protected herbaceous vegetation had the highest evenness values (median=0.99) while unprotected open trees had the lowest median value at 0.93 .

Table 4 Basal area of mature hardwood tree species preferred for charcoal production in the protected and unprotected woodlands

\begin{tabular}{|c|c|c|c|c|}
\hline \multirow{2}{*}{ Land-cover class } & \multicolumn{2}{|c|}{ Protected woodland } & \multicolumn{2}{|c|}{ Unprotected woodland } \\
\hline & Mean basal area $\left(\mathrm{hm}^{2}\right)$ & Standard deviation & Mean basal area $\left(\mathrm{hm}^{2}\right)$ & Standard deviation \\
\hline Open trees & 3.85 & 1.07 & 1.50 & 0.76 \\
\hline Thickets & 1.80 & 2.29 & 0.89 & 1.21 \\
\hline Shrubs & 1.97 & 0.50 & 1.77 & 1.84 \\
\hline Herbaceous vegetation & 0.71 & 0.27 & 1.00 & 0.82 \\
\hline
\end{tabular}

Table 5 Pairwise comparisons of densities for mature trees and saplings between corresponding land-cover types in protected and unprotected woodlands

\begin{tabular}{|c|c|c|c|c|c|c|}
\hline \multirow{3}{*}{ Land-cover class } & \multicolumn{3}{|c|}{ Density of mature trees } & \multicolumn{3}{|c|}{ Density of saplings } \\
\hline & \multicolumn{2}{|c|}{ Median (individuals $/ \mathrm{hm}^{2}$ ) } & \multirow[b]{2}{*}{ Two-tailed $P$} & \multicolumn{2}{|c|}{ Median (individuals $/ \mathrm{hm}^{2}$ ) } & \multirow[b]{2}{*}{ Two-tailed $P$} \\
\hline & $\begin{array}{c}\text { Protected } \\
\text { woodlands }\end{array}$ & $\begin{array}{c}\text { Unprotected } \\
\text { woodlands }\end{array}$ & & $\begin{array}{c}\text { Protected } \\
\text { woodlands }\end{array}$ & $\begin{array}{c}\text { Unprotected } \\
\text { woodlands }\end{array}$ & \\
\hline Open trees & 300 & 337 & 0.662 & 75 & 113 & 0.931 \\
\hline Thickets & 350 & 225 & 0.071 & 50 & 150 & 0.063 \\
\hline Shrubs & 350 & 288 & 0.476 & 100 & 75 & $0.019^{*}$ \\
\hline $\begin{array}{l}\text { Herbaceous } \\
\text { vegetation }\end{array}$ & 250 & 250 & 1.000 & 100 & 163 & 0.286 \\
\hline
\end{tabular}

Note: * indicates significance at $P<0.05$ level.

Table 6 Pairwise comparisons of species richness, evenness and Shannon diversity between corresponding land-cover types in protected and unprotected woodlands

\begin{tabular}{|c|c|c|c|c|c|c|c|c|c|c|c|c|}
\hline \multirow{3}{*}{$\begin{array}{c}\begin{array}{c}\text { Land-cover } \\
\text { class }\end{array} \\
\text { Open trees }\end{array}$} & \multicolumn{4}{|c|}{ Species richness } & \multicolumn{4}{|c|}{ Evenness } & \multicolumn{4}{|c|}{ Shannon diversity } \\
\hline & \multicolumn{2}{|c|}{ Median } & \multirow{2}{*}{$\frac{\mathrm{U}}{13.0}$} & \multirow{2}{*}{$\frac{P}{0.708}$} & \multicolumn{2}{|c|}{ Median } & \multirow{2}{*}{$\frac{\mathrm{U}}{11.0}$} & \multirow{2}{*}{$\frac{P}{0.465}$} & \multicolumn{2}{|c|}{ Median } & \multirow{2}{*}{$\frac{\mathrm{U}}{13.0}$} & \multirow{2}{*}{$\begin{array}{c}P \\
0.715\end{array}$} \\
\hline & 5.0 & 5.5 & & & 0.97 & 0.93 & & & 1.6 & 1.7 & & \\
\hline Thickets & 5.0 & 4.0 & 34.5 & 0.069 & 0.97 & 0.95 & 38.0 & 0.108 & 1.6 & 1.3 & 30.0 & $0.045^{*}$ \\
\hline Shrubs & 7.0 & 6.0 & 8.0 & 0.374 & 0.98 & 0.98 & 7.0 & 0.286 & 1.9 & 1.7 & 6.0 & 0.201 \\
\hline $\begin{array}{l}\text { Herbaceous } \\
\text { vegetation }\end{array}$ & 5.0 & 3.5 & 8.5 & 0.669 & 0.99 & 0.95 & 6.0 & 0.327 & 1.5 & 1.1 & 7.0 & 0.462 \\
\hline
\end{tabular}

Note: ${ }^{*}$ indicates significance at $P<0.05$ level.

\subsection{Tree stumps and coppicing in the unprotected woodlands}

Within the unprotected woodlands, the highest numbers of stumps were recorded in the thickets followed by the shrubs as shown in Table 7. The open trees had the highest percentage of 
coppiced tree stumps at $81 \%$ while only $52 \%$ of the stumps had coppiced in the shrubs. However, the contribution of coppices to the overall number of saplings was highest in the shrubs and open trees at $38 \%$ in both cases. The lowest contribution of the coppices to the saplings density was in the herbaceous vegetation at $20 \%$.

Table 7 Density of tree stumps and contribution of coppices to the total density of saplings in the unprotected woodlands

\begin{tabular}{lccc}
\hline Land-cover class & $\begin{array}{c}\text { Stumps density } \\
\left.\text { (individuals } / \mathrm{hm}^{2}\right)\end{array}$ & $\begin{array}{c}\text { Percentage of coppicing stumps } \\
(\%)\end{array}$ & $\begin{array}{c}\text { Percentage of coppice saplings } \\
(\%)\end{array}$ \\
\hline Open trees & 50 & 81 & 38 \\
Thickets & 65 & 64 & 32 \\
Shrubs & 58 & 52 & 38 \\
Herbaceous vegetation & 38 & 72 & 20 \\
\hline
\end{tabular}

\subsection{Canonical correspondence analysis}

The canonical correspondence analysis (CCA) triplot in Fig. 3 presents the community variation between samples and explains the differences in species composition in relation to environmental variables. The triplot shows the distribution of the samples differentiated according to their land-cover classes and protection status together with the tree species and environmental variables. The first ordination axis can be interpreted as representing protection status, correlating to $56 \%$ with this environmental variable and $61 \%$ with the related variables of the numbers of kilns and tree stumps found only within the unprotected woodlands. The majority of the unprotected sampling plots are located in the left quadrants while the protected plots are located in the right. Nevertheless, the plots sampled within the herbaceous vegetation are not separated by protection status and are all found in the right quadrants. This shows that these samples do not differ floristically in respect to the sampled tree species composition.

The second ordination axis can be interpreted as sorting the species according to hardness and preference for charcoal production, with the species scores of hardwood species like Acacia lahai, Acacia nilotica, Acacia seyal, Acacia senegal, Berchemia discolor, Grewia bicolor and Dalbergia melanoxylon being mostly found within the top quadrants and the species scores of the softwood species like Saba comorensis, Commiphora africana, Commiphora ellenbeckii, Lannea schweinfurthii and Albizia anthelmintica at the bottom. As the species scores in CCA are the weighted averages of the sampling plots scores, respective species are scattered in close proximity to the sampling plots which contain them. Many of the plots from the unprotected woodlands and thickets therefore seem to contain higher amounts of softwood species while plots from protected woodlands contain higher amounts of hardwood species. Based on the same argument, it can be seen that the highest number of tree stumps were found in unprotected thickets which also has the highest number of charcoal kilns. The CCA ordination diagram also shows that the highest number of saplings was found within sampling plots in the unprotected thickets.

\section{Discussion}

The study shows that there is a significant difference in tree composition between the protected and the unprotected woodlands in terms of hardwoods basal area, mature trees density, species richness, evenness and Shannon diversity. Moreover, the CCA ordination diagram confirms this difference in tree composition through a clear separation of the plots in the protected woodlands from those in the unprotected woodlands. More importantly, the values of important indicators of the unprotected woodlands are lower than those of the protected woodlands except for mature trees density, signifying a state of degradation. Charcoal production has been identified as a major activity within the unprotected woodlands and therefore would be assumed to be a major contributor to this degradation. This assumption was validated through a logistic regression model using the number of recorded tree stumps per land-cover as the dependent variable and the number of charcoal kilns as the independent variable. The results of the logistic regression model 


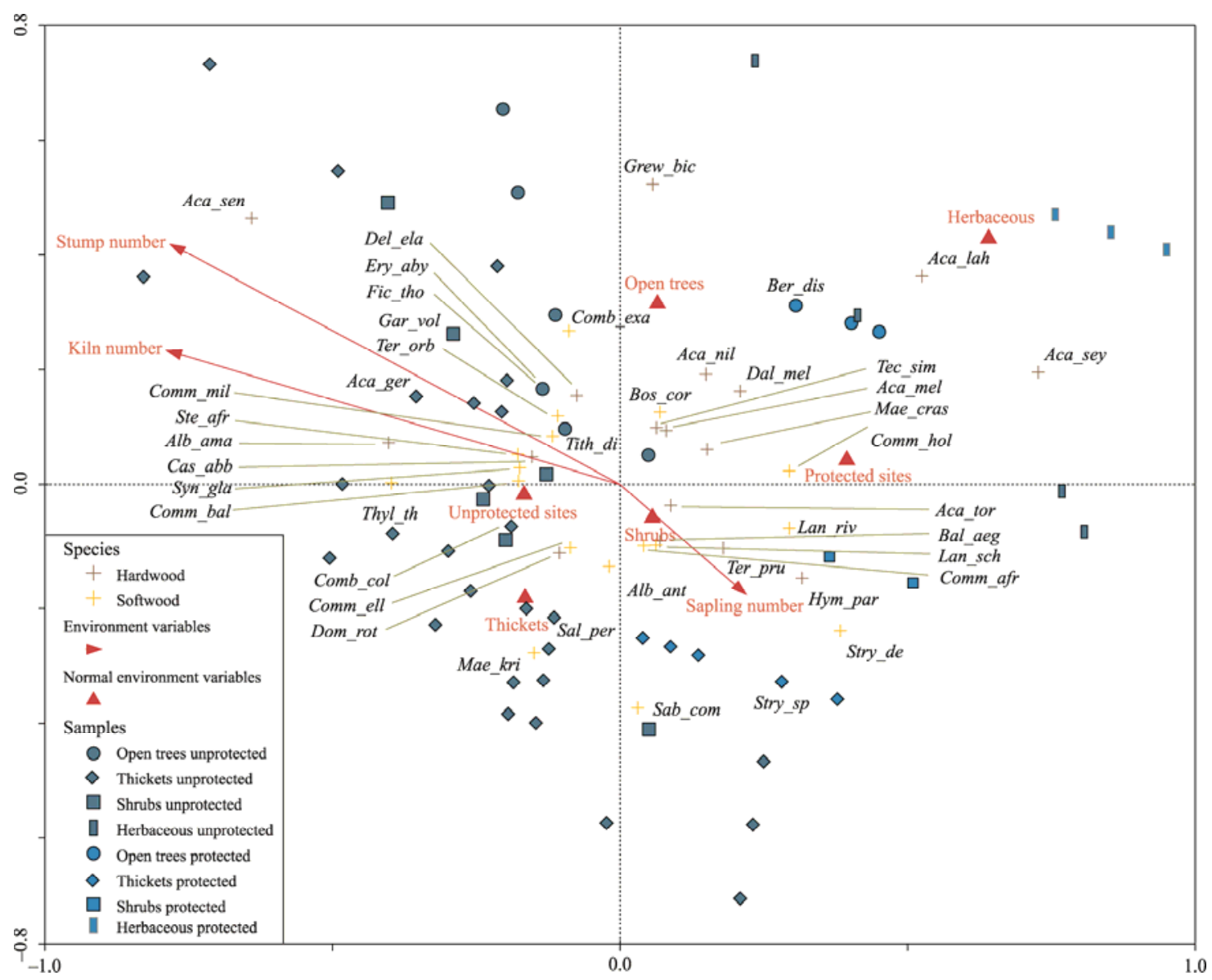

Fig. 3 Canonical correspondence analysis (CCA) plot showing the analyzed environmental variables and the distribution of mature tree species and sampling plots within the ordination space. The plot spanned up by the first two axes of a CCA that together explain $47.7 \%$ variance of the species-environment relation. The eigenvalues of axis 1 (horizontally) and axis 2 (vertically) are 0.240 and 0.118 , respectively; and their species-environment correlations are 0.779 and 0.664 , respectively. Species are labelled by the first three letters of their generic names followed by the first three letters of their specific names. The complete list of tree species is presented in Table 2 . Notes on data processing: species data were used without scalar transformation, and rare species were down-weighted to decrease their importance (as CCA is highly sensitive to rare species; Shaw, 2003). The nominal environmental variables are the categorical variables of the land-cover classes and protection status, which had to be processed as "dummy" variables, and their symbols in the ordination plot represent the centroids of the sample groups defined by them.

showed that the main purpose for harvested trees in the study area is charcoal production as the number of tree stumps could be explained by the number of charcoal kilns. As the density of mature trees in the unprotected woodlands is higher than in the protected ones, but the hardwoods basal area is less, we conclude that there is more active recruitment of softwood tree species after selectively harvesting the hardwoods for charcoal production. Similarly, other studies have also shown that woodlands subjected to charcoal production are more likely to have less tree density, basal area and tree diversity (Luoga et al., 2002; Butz, 2013; Chidumayo and Gumbo, 2013).

The woodlands are comprised of different land-cover classes, which naturally have differences in tree composition due to varying environmental and biophysical conditions (e.g. climatic and edaphic variables as well as topography and sunlight exposure). For example, a factor like topography may affect the accessibility of the trees stock by charcoal producers (Luoga et al., 2002), while other habitat characteristics might affect the rate of recovery of the woodlands after perturbation (Luoga et al., 2004; de Figueirôa et al., 2006; Zida et al., 2007; Chidumayo, 2013). As such, the status of the land-cover may be a direct result of the land-use in 
combination with the environmental and biophysical factors. For this reason, the study sought to find out if there was a significant difference in tree composition and structure between corresponding land-covers in the protected and unprotected woodlands.

In terms of basal area, the pairwise comparison of the corresponding land-covers gave a deeper insight into the trend of degradation at the land-cover level. More interestingly, the basal area of the hardwood tree species, usually targeted for charcoal production, is significantly lower in the open trees of the unprotected compared to the protected woodlands. Moreover, even though the Mann-Whitney U test did not reveal any significant difference in the basal area of hardwood trees between the other land-cover classes, the general trend showed that the basal area is higher in the protected woodlands than in the unprotected woodlands.

As charcoal kilns and tree stumps (main indicators of charcoal production) were identified in all the unprotected land-cover classes, it can be concluded that charcoal production through selective logging has a negative impact on the basal area of targeted species, and that the open trees land-cover class is especially affected. A large part of the open trees is found on hills considered as important water catchment areas (Eriksen et al., 2006) where settlements are discouraged by the local authorities. Nevertheless, charcoal production still takes place due to lack of a strict protection regime, risking the livelihoods of the people who depend on the woodlands as a water catchment.

Even though not significant, the land-cover classes in the protected woodlands had a higher median number of species than the unprotected woodlands except in the open trees. This higher species richness in the unprotected open trees is consistent with findings by Banda et al. (2006) that species richness was generally higher in disturbed plots. The authors argue that there is a likelihood of light-demanding pioneer species that were not present before, being recruited in the open spaces due to better light penetration and reduced competition for water and nutrients. However, Zida et al. (2007) also explained that the opened-up spaces could easily be colonized by grasses and shrubs which suppress regeneration from seeds and consequently new species recruitment. There is a high likelihood that this is what has led to the lower median number of tree species in the other land-cover classes as they all have a thick layer of shrubs and herbaceous vegetation undergrowth unlike the open trees class which is dominated by trees (FAO, 2002). Reduction in species richness might thus result from lack of coppicing ability of some harvested mature trees coupled with suppressed regeneration from seedlings.

The herbaceous vegetation has the least number of species in both the protected and unprotected woodlands, a status Banda et al. (2006) referred to as "floral poor", and that might be connected more to natural site conditions than to anthropogenic perturbation. As mentioned earlier, this land-cover type has clayey soils which are poorly drained and have low fertility.

As is the case with species richness, the open trees in the unprotected woodlands had higher Shannon diversity and evenness indices, though not statistically significant. We conclude just as in the case of species richness presented before, that the ability of this land-cover class to recruit new members in the opened- up spaces after selective harvesting leads to higher Shannon and evenness values in the unprotected woodlands. The Shannon and evenness indices were generally lower (or equal in the case of the evenness for the shrubs) in the unprotected woodlands for the other land-cover classes. The difference was especially statistically significant for the Shannon diversity between the protected and unprotected thickets. Reduced or lack of recruitment of new tree species due to suppression by the grass and shrubs undergrowth as mentioned earlier could be directly responsible for the low indices in these land-cover classes. Chidumayo (2013) reported similar significant negative impacts on tree diversity in Miombo woodlands in Zambia after perturbation (through fire, selective harvesting for poles, charcoal and bark fibre).

Mature trees density analysis at the land-cover level showed that there was no significant difference between corresponding land-cover classes in the unprotected and protected woodlands. However, the unprotected open trees had a higher median of mature trees density compared to the protected. As the basal area of the hardwood trees in this land-cover class was found to be significantly lower in the unprotected woodlands, the land-cover, even though not significantly affected in terms of mature trees density, has had its composition switched towards softwoods 
dominance. In the other land-cover classes, the median of mature trees density is generally higher in the protected woodlands (except in herbaceous vegetation where they are equal), even though not statistically significant. We conclude that the mature trees are less in these unprotected land-covers as a direct impact of selective logging. The median density of saplings in the unprotected woodlands is generally higher (except in the shrubs), but this could be for varying reasons. For the unprotected open trees, this could be because of the high rate of regeneration in the opened-up spaces (Banda et al., 2006; Zida et al., 2007; Chidumayo and Gumbo, 2013). For the other land-covers, this could be because of the stunted growth of regenerating trees due to suppression from the grass and shrubs undergrowth layers which means they remain below a $\mathrm{DBH}$ of $5 \mathrm{~cm}$. However, as the saplings density is relatively higher in the disturbed woodlands, the woodlands have the capacity to recover if well managed. Indeed, Chidumayo (2013) and Luoga et al. (2004) reported that the density and distribution of saplings in a perturbed woodland give an indication of its ability to recover.

The majority of the stumps were resprouting, further contributing to the regeneration process except in the shrubs, where only $52 \%$ of the stumps had resprouted. Several authors have highlighted the importance of regeneration through coppicing in recovery of dry forests and woodlands (Luoga et al., 2002, 2004; de Figueirôa et al., 2006; Zida et al., 2007; Chidumayo, 2013). These authors also reported that the effectiveness of coppicing is affected by: site conditions (sunlight exposure, soil type, fertility and depth), stump factors (species, height, tree age, size, smoothness of cut) and weather conditions (with best results reported when felling was done just before the rains). Though not investigated, a combination of these factors might have led to differences in coppicing rates in different land-covers.

The coppices made sizeable contributions to the number of saplings in the unprotected woodlands, accounting for $38 \%$ of the saplings in both the open trees and shrubs. It is however important to point out that some of the other saplings could have regenerated from the root crown but this could not be easily ascertained. As such, not all the remaining saplings can be considered as originating from seedlings. However, Chidumayo (2013) stated that even though many trees in dry woodlands have the capacity to coppice, regeneration is normally dominated by saplings of seedlings origin. It would therefore be expected that most of the other saplings were also of seedlings origin.

\section{Conclusions}

On the basis of the findings from this study, we conclude that charcoal production through selective logging leads to degradation of the dry woodlands. The degradation is manifested through reduction in preferred tree species density and basal area. In addition, the affected woodlands have a significantly lower number of tree species, lower Shannon diversity and evenness. At the land-cover level, the study established that the impact is varied depending on the site conditions of the affected land-covers. The species richness, evenness and Shannon diversity are likely to increase in woodlands where seedlings recruitment freely takes place in the opened-up spaces through selective logging. However, in cases where there is a thick undergrowth layer of grass and shrubs, these opened-up spaces are quickly colonized by the undergrowth, suppressing seedlings growth and consequently causing a reduction in tree species richness, evenness and Shannon diversity.

Specifically, the study found the most significant impact of charcoal production in the open trees which has a high density of the preferred tree species in large sizes. We therefore accept the study's hypothesis that the unprotected woodlands subjected to charcoal production are significantly degraded compared to those that are protected but that the nature and level of the impact depends on the environmental conditions of the respective land-covers. With these findings, this study sheds light on the degrading impact of selective harvesting for charcoal production on dry woodlands, an issue that has generally divided opinions among researchers. 


\section{Acknowledgements}

The authors would like to acknowledge the financial assistance accorded by the World Agroforestry Center (ICRAF) and the Center for Natural Resources and Development (CNRD) of TH Köln University of Applied Sciences without which this study would not have been possible. Furthermore we would like to thank the foresters, enumerators and participating communities who worked hard to make the study a success. Finally, we would like to thank the anonymous reviewers for their valuable comments on the previous draft of this paper.

\section{References}

Ahrends A, Burgess N D, Milledge S A H, et al. 2010. Predictable waves of sequential forest degradation and biodiversity loss spreading from an African city. Proceedings of the National Academy of Sciences of the United States of America, 107(33): $14556-14561$.

Archibald S, Scholes R J. 2007. Leaf green-up in a semi-arid African savanna-separating tree and grass responses to environmental cues. Journal of Vegetation Science, 18(4): 583-594.

Arnold J E M, Köhlin G, Persson R. 2006. Woodfuels, livelihoods, and policy interventions: changing perspectives. World Development, 34(3): 596-611.

Banda T, Schwartz M W, Caro T. 2006. Woody vegetation structure and composition along a protection gradient in a Miombo ecosystem of western Tanzania. Forest Ecology and Management, 230(1-3): 179-185.

Becknell J M, Kucek L K, Powers J S. 2012. Aboveground biomass in mature and secondary seasonally dry tropical forests: a literature review and global synthesis. Forest Ecology and Management, 276: 88-95.

Butz R J. 2013. Changing land management: a case study of charcoal production among a group of pastoral women in northern Tanzania. Energy for Sustainable Development, 17(2): 138-145.

Chidumayo E N, Gumbo D J. 2010. The Dry forests and woodlands of Africa: Managing for Products and Services. London: Earthscan.

Chidumayo E N. 2013. Forest degradation and recovery in a miombo woodland landscape in Zambia: 22 years of observations on permanent sample plots. Forest Ecology and Management, 291: 154-161.

Chidumayo E N, Gumbo D J. 2013. The environmental impacts of charcoal production in tropical ecosystems of the world: a synthesis. Energy for Sustainable Development, 17(2): 86-94.

de Figueirôa J M, Pareyn F G C, de Lima Araújo E, et al. 2006. Effects of cutting regimes in the dry and wet season on survival and sprouting of woody species from the semi-arid caatinga of northeast Brazil. Forest Ecology and Management, 229(1-3): 294-303.

De la Barreda-Bautista B, López-Caloca1 A A, Couturier S, et al. 2011. Tropical dry forests in the global picture: the challenge of remote sensing-based change detection in tropical dry environments. In: Carayannis E. Planet Earth 2011-Global Warming Challenges and Opportunities for Policy and Practice. [S.1.]: InTech, 231-257.

Eriksen S, Gachathi F N, Muok B, et al. 2006. Synergies in biodiversity conservation and adaptation to climate change: the case of hilltop forests in Kitui, Kenya. In: Mistry J, Berardi A. Savannas and Dry Forests. London, UK: Ashgate.

FAO. 2000. Management of Natural Forests of Dry Tropical Zones. Rome: The FAO.

FAO. 2002. Multipurpose landcover database for Kenya-Africover. FAO. http://www.fao.org/geonetwork/srv/en/metadata.show? $\mathrm{id}=38098 \&$ currTab $=$ simple.

GOK. 2009. Kibwezi district development plan 2008-2012. Nairobi: The Government Printers.

GOK. 2013. Analysis of the charcoal value chain in Kenya. Nairobi: Ministry of Environment, Water and Natural Resources.

Grace J, San José J, Meir P, et al. 2006. Productivity and carbon fluxes of tropical savannas. Journal of Biogeography, 33(3): 387-400.

Grainger A. 1999. Constraints on modelling the deforestation and degradation of tropical open woodlands. Global Ecology and Biogeography, 8(3-4): 179-190.

Iiyama M, Neufeldt H, Dobie P, et al. 2014. The potential of agroforestry in the provision of sustainable woodfuel in sub-Saharan Africa. Current Opinion in Environmental Sustainability, 6: 138-147.

le Polain de Waroux Y, Lambin E F. 2012. Monitoring degradation in arid and semi-arid forests and woodlands: the case of the argan woodlands (Morocco). Applied Geography, 32(2): 777-786.

Luoga E J, Witkowski E T F, Balkwill K. 2002. Harvested and standing wood stocks in protected and communal miombo woodlands of eastern Tanzania. Forest Ecology and Management, 164(1-3): 15-30.

Luoga E J, Witkowski E T F, Balkwill K. 2004. Regeneration by coppicing (resprouting) of miombo (African savanna) trees in relation to land use. Forest Ecology and Management, 189(1-3): 23-35. 
Maass J M, Balvanera P, Castillo A, et al. 2005. Ecosystem services of tropical dry forests: insights from long-term ecological and social research on the Pacific Coast of Mexico. Ecology and Society, 10(1): 1-23.

Millington A C, Critchley R W, Douglas T D, et al. 1994. Estimating Woody Biomass in Sub-Saharan Africa. Washington DC: The World Bank.

Mutiti C M. 2010. Landscape structure of Acacia-commiphora bushland in Southeastern Kenya. PhD Dissertation. USA: Miami University.

Ngene S, Njumbi S, Nzisa M, et al. 2013. Status and trends of the elephant population in the Tsavo-Mkomazi ecosystem. Pachyderm, (53): 38-50.

Pielou E C. 1975. Ecological Diversity. New York: John Wiley \& Sons Inc.

Mugova A. 2009. Assessing livelihoods impact of charcoal production in Bondo and Kitui Districts of Kenya: a value chain analysis approach. Prepared by PAC for Pisces charcoal Kenya Nov 2009 Workshop; extracted from PAC report to UNDP Kenya on "sustainable charcoal Production in Four Districts in Kenya". Nairobi: Practical Action.

Shaw P J A. 2003. Multivariate Statistics for the Environmental Sciences. New York: Oxford University Press.

Ter Braak C J F. 1987. The analysis of vegetation-environment relationships by canonical correspondence analysis. Vegetatio, 69(1-3): 69-77.

Ter Braak C J F, Šmilauer P. 2002. CANOCO Reference Manual and CanoDraw for Windows User's Guide: Software for Canonical Community Ordination (version 4.5). Ithaca NY, USA: Microcomputer Power.

The Angiosperm Phylogeny Group. 2009. An update of the angiosperm phylogeny group classification for the orders and families of flowering plants: APG III. Botanical Journal of the Linnean Society, 161(2): 105-121.

Whittaker R H. 1972. Evolution and measurement of tree species diversity. Taxon, 21(2-3): 213-251.

Zida D, Sawadogo L, Tigabu M, et al. 2007. Dynamics of sapling population in savanna woodlands of Burkina Faso subjected to grazing, early fire and selective tree cutting for a decade. Forest Ecology and Management, 243(1): 102-115. 